\title{
Heat Curing Behavior of Light-cured Composite Resins Investigated by Dynamic Differential Scanning Calorimetry
}

\author{
Seiji BAN, Yosifumi TAKAHASHI, Hiroaki TANASE and Jiro HASEGAWA \\ Department of Dental Materials Science, School of Dentistry, Aichi-Gakuin University, 1-100, \\ Kusumoto-cho, Chikusa-Ku, Nagoya 464, Japan
}

Received on May 14, 1990

Accepted on September 21, 1990

The heat curing behavior of light-cured restorative composite resins, light-cured crown and bridge veneering resins, pure dimethacrylate monomers, Bis-GMA monomers containing various initiators, and monomer mixtures were investigated by slow heating at a constant rate with differential scanning calorimetry (DSC) without any light irradiation-the so-called dynamic DSC measurement. Some of the lightcured restorative composite resins and the light-cured crown and bridge veneering resins showed a sharp exothermic peak due to heat curing. Pure TEDMA also showed a sharp exothermic peak, whereas the BisGMA monomers containing catalysts for light curing showed no exothermic peak. It seems that heat curing behavior of light-cured composite resins depends not on the decomposition of camphorquinone, but on that of the monomer itself.

Key words : Light-cured composite resins, DSC, Heat curing

\section{INTRODUCTION}

Visible light-cured composite resins have been extensively applied in modern cosmetic dentistry instead of chemically cured composite resins. Furthermore, light-cured composite resins tend to be used for the reinforcement of the mechanical properties of composite resin inlays by heat treatment. It has been previously reported that the properties of light-cured composite resins can be improved by a secondary application of heat ${ }^{1-4)}$. It is thus necessary to understand the thermal polymerization behavior of light-cured composite resins to clarify why such improvements occur upon heating.

Most of visible light-cured resins contain a photosensitizer like camphorquinone, and a reducing like tertiary amine ${ }^{5-8}$ which cause the initiation of polymerization by visible light irradiation. It is important to study the initial polymerization of these resins, because various properties of the set resins are doubtlessly affected by the degree of polymerization ${ }^{9)}$. The polymerization reaction of dental composite resins has been investigated by various methods including infrared spectroscopy (IR), ${ }^{10,11)}$ differential thermal analysis (DTA), ${ }^{12,13)}$ and differential scanning calorimetry (DSC $)^{14,15}$. In particular, DSC can be easily used to measure the heat of polymerization, reaction kinetics, degree of conversion, and other factors for a variety of chemically cured composite resins. Moreover, the properties of dimethacrylate monomers can be measured by the isothermal ${ }^{16-19)}$ or heating method ${ }^{20)}$, and the heat of polymerization of light-cured composite resins by light irradiation as well can be measured by isothermal DSC measurement ${ }^{21-23)}$. We have already reported that light-cured crown and bridge veneering resins showed an exothermic peak in the DSC curve when slowly heated 
from room temperature to $200^{\circ} \mathrm{C}$ without any light irradiation ${ }^{24)}$.

The purpose of this investigation is to study the heat curing of light-cured composite resins and dimethacrylate monomers by slow heating at a constant rate. Here, we employ DSC without light irradiation-the so-called dynamic DSC measurement-and discuss the heat curing behavior of commercial light-cured composite resins.

\section{MATERIALS AND METHOD}

The investigated materials, code, batch numbers, and manufacturers are listed in Table 1. Four visible light-cured restorative composite resin products, PCA, LF, OC, and PF were used. $\mathrm{CF}-\mathrm{C}$ and $\mathrm{CF}-\mathrm{U}$ were chemically cured composite resin pastes, catalyst and universal,

Table 1 Materials used

\begin{tabular}{|c|c|c|c|c|}
\hline Type $^{*}$ & Materials & Code & Batch No. & Manufacturer \\
\hline \multicolumn{5}{|c|}{ Restorative Composite Resins } \\
\hline $\mathrm{L}$ & Photo Clearfil A & PCA & 1172 & Kuraray \\
\hline $\mathrm{L}$ & Lite-fil A & $\mathrm{LF}$ & 018559 & Shofu \\
\hline $\mathrm{L}$ & Occlusin & $\mathrm{OC}$ & HH13 & ICI \\
\hline $\mathrm{L}$ & Pyrorafil Light-A & PF & 502 & Sankin \\
\hline $\mathrm{C}$ & Clearfil F-II Catalyst & $\mathrm{CF} \cdot \mathrm{C}$ & 20043 & Kuraray \\
\hline $\mathrm{C}$ & Clearfil F-II Universal & $\mathrm{CF} \cdot \mathrm{U}$ & 20043 & Kuraray \\
\hline \multicolumn{5}{|c|}{ Crown and Bridge Veneering Resins } \\
\hline $\mathrm{L}$ & Thermoresin LC & LC & 020371 & GC \\
\hline $\mathrm{L}$ & Dentacolor & DC & 701023 & Kulzer \\
\hline $\mathrm{L}$ & Metacolor & $\mathrm{MC}$ & 70401 & Sunmedical \\
\hline $\mathrm{H}$ & SR-Isosit-N & IS & 6031 & Ivoclar \\
\hline $\mathrm{H}$ & Biolon & BO & 20183,080185 & Caulk \\
\hline $\mathrm{H}$ & Thermoresin & $\mathrm{TR}$ & 140561,220761 & GC \\
\hline $\mathrm{H}$ & Plastique & $\mathrm{PL}$ & 058258,078687 & Shofu \\
\hline \multicolumn{5}{|c|}{ Monomers } \\
\hline Met & hyl-methacrylate & MMA & $\mathrm{C} 0366$ & Yoneyama Yakuhin \\
\hline Ethy & yl-methacrylate & EMA & A001 & Tokyo Kasei \\
\hline Ethy & lene-glycol-dimethacrylate & EDMA & A 003 & Tokyo Kasei \\
\hline Trie & thylene-glycol-dimethacrylate & TEDMA & AW01 & Tokyo Kasei \\
\hline \multicolumn{5}{|c|}{$\mathrm{Di}$ (methacryloxy-ethyl) -trimethyl-hexamethylene-diurethane } \\
\hline & & UDMA & 620908 & Shin-Nakamura \\
\hline \multicolumn{5}{|c|}{ 2, 2-bis [4 (2-hydroxy-3 methacryloxy-propyloxy)-phenly] propane } \\
\hline & & Bis-GMA & $0416 \mathrm{~W}$ & Shin-Nakamura \\
\hline \multicolumn{5}{|c|}{ 2, 2-bis [4-methacryloxy-polyethoxy-phenyl $]$ propane $(n=2.6)$} \\
\hline & & Bis-MPEPP & $0624 \mathrm{~A}$ & Shin-Nakamura \\
\hline \multicolumn{5}{|c|}{ Reagents } \\
\hline Benz & zoylperoxide & $\mathrm{BPO}$ & TSR3473 & Wako Pure Chemical \\
\hline Com & iphorquinone & $\mathrm{CQ}$ & FCW01 & Tokyo Kasei \\
\hline Dim & ethyl paratoluidine & DMPT & A001 & Tokyo Kasei \\
\hline Dim & ethylaminoethyl methacrylate & DMAEMA & A002 & Tokyo Kasei \\
\hline Trie & thylamine & TEA & A002 & Tokyo Kasei \\
\hline
\end{tabular}

${ }^{*} \mathrm{~L}:$ : Light-cured

$\mathrm{C}:$ Chemically cured

$\mathrm{H}$ : Heat-cured 
respectively. Seven crown and bridge veneering resin products were used; $L C, D C$, and MC were visible light-cured resins, and IS, BO, TR, and PL were heat-cured ones. The composition of these commercial products is given in Table 2 from references ${ }^{25-29)}$.

Table 2 Composition of materials (wt\%)

\begin{tabular}{lll}
\hline \multicolumn{1}{c}{ Materials } & \multicolumn{1}{c}{ Monomer } & Reference No \\
\hline Restorative & Composite Resins & \\
PCA & Bis-GMA (67), TEDMA (21) & $25,26,27$ \\
LF & UDMA, TEDMA & 25,26 \\
OC & UDMA, TEDMA & 25,26 \\
PF & Bis-GMA & 26 \\
CF-C & Bis-GMA (18.5), TEDMA (6.3), BPO & 28 \\
CF-U & Bis-GMA & 28 \\
\hline Crown and & Bridge Veneering Resins & \\
LC & UDMA (12), NPGDMA (9) & 29 \\
DC & UDMA (50), TEDMA (7) & 29 \\
MC & UDMA (78) & 29 \\
IS & UDMA (46), 1, 4 BuDMA (11) & 29 \\
BO & MMA (70), TEDMA (17), EDMA (11) & 29 \\
TR & Bis-MPEPP (100) & 29 \\
PL & TEDMA (70), Bis-MPEPP (30) & 29 \\
\hline
\end{tabular}

Four types of monomers were used without any additives and purification. Furthermore, 8 kinds of mixtures of Bis-GMA and catalysts were prepared : A, 2 wt $\%$ BPO ; B, 2 wt $\% \mathrm{CQ}$; C, 2 wt \% DMPT ; D, 2 wt \% DMAEMA ; E, 2 wt $\%$ TEA ; F, 2 wt\% CQ + 2 wt $\%$ DMPT ; G, 2 wt $\% \mathrm{CQ}+2 \mathrm{wt} \%$ DMAEMA ; $\mathrm{H}, 2 \mathrm{wt} \% \mathrm{CQ}+2 \mathrm{wt} \% \mathrm{TEA}$. Seven kinds of monomer mixtures were prepared from "as received" monomers : I, UDMA-10 wt\% TEDMA ; 058L, Bis-GMA-30 wt\% TEDMA ; M, Bis-GMA-10 wt\% MMA ; N, Bis-GMA-10 wt\% EMA ; O, Bis-GMA-10 wt $\%$ EDMA.

A differential scanning calorimeter* was used to make measurements. Small samples (30 $-40 \mathrm{mg}$ ) of each material were weighed out into an aluminum sample pan. The samples were then slowly heated at a constant rate $\left(10^{\circ} \mathrm{C} / \mathrm{min}\right)$ from room temperature to $200^{\circ} \mathrm{C}$. DSC range was $\pm 16 \mathrm{mcal} / \mathrm{s}$. The experiments were conducted under ordinay atmospheric conditions and the sample pan was not hermetically sealed.

\section{RESULTS AND DISCUSSION}

Figure 1 shows the change in DSC curves during the heating of restorative composite resins. In the case of visible light-cured composite resins, PCA showed a sharp exothermic peak at around $110^{\circ} \mathrm{C}$, and $P F$ showed a broad exothermic peak around $160^{\circ} \mathrm{C}$, while $\mathrm{LF}$ and OC showed no exothermic peak. Afrer measurement, PCA set, but LC, OC, and PF did not. Therefore, it seems that this exothermic peak of PCA depended on the heat of polymerization. Chemically cured resin was not mixed. $\mathrm{CF}-\mathrm{C}$, the catalyst which contains BPO for the

* Rigaku, standard model, Tokyo, Japan 
initiation of radical polymerization, showed a sharp exothermic peak around $100^{\circ} \mathrm{C}$. It is clear that this peak depended on the heat of polymenrization initiated by heat decomposition of BPO.

$\mathrm{CF}-\mathrm{U}$, the universal paste which contains tertiary amine for acceleration of decomposition of BPO, showed no exothemic peak.

Figure 2 shows the change in DSC curves during the heating of crown and bridge veneering resins. In the case of visible light-cured resins, $\mathrm{MC}$ showed a sharp exothermic peak around $130^{\circ} \mathrm{C}$, and LC showed 2 broad peaks around $150^{\circ} \mathrm{C}$ and $180^{\circ} \mathrm{C}$, and $\mathrm{DC}$ showed a broad peak. After the measurement, MC set, while LC and DC set only slightly. Thus, it seems that these exothermic peaks were due to the heat of polymerization. On the other hand, the thermally cured resins, IS, BO, TR, and PL showed a sharp exothemic peak around $100-120^{\circ} \mathrm{C}$. The peak for IS was smaller than that of the other thermally cured resins, because it contains a large amount of filler and a relatively small amount of monomer, mainly UDMA, and the other thermally cured resins contain no filler, as shown in Fig. 2.

Figure 3 shows the change in DSC curves during the heating of 4 monomers without any kind of additives. A relatively large exothermic peak was observed around $150^{\circ} \mathrm{C}$ in the DSC

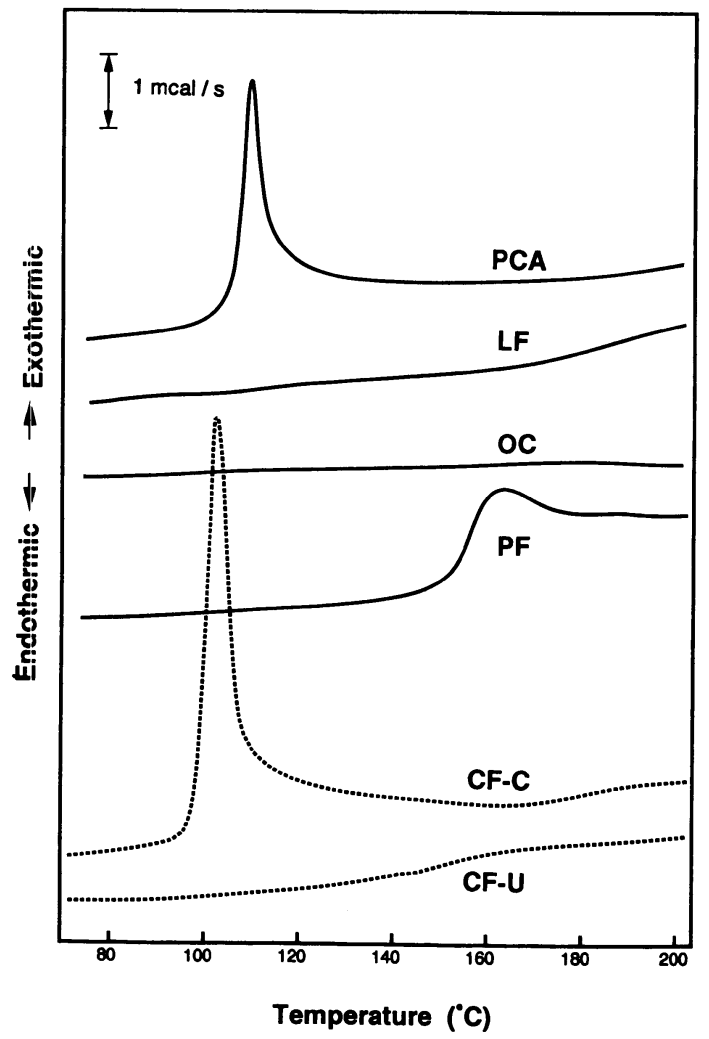

Fig. 1 Change in DSC curves during heating of restorative composite resins. Solid lines show visible light-cured resin pastes and broken lines show chemically. cured. 
curve for TEDMA. Bis-MPEPP showed 2 exothermic peaks around $160^{\circ} \mathrm{C}$ and $180^{\circ} \mathrm{C}$. UDMA had an exothermic peak around $170^{\circ} \mathrm{C}$. However, Bis-GMA had no exothermic peak in this temperature range. Furthermore, after the measurement, the sub-surface of TEDMA in the sample pan had set, though the surface layer of the monomer had not due to inhibition by atmospheric oxygen. The setting behavior of Bis-MPEPP and UDMA were nearly identical to TEDMA, but these monomers had a relatively low extent of polymerization compared with that of TEDMA. It seems that peak depended on the heat of polymerization, because the sample hardened after the measurement. The peak height, area, and temperature of the exothermic peak in the DSC curve for TEDMA changed with each brand and lot.

Miyazaki et al. ${ }^{17)}$ demonstrated that both the rate and extent of polymerization of BisGMA were lower than TEDMA, UDMA and Bis-MPEPP in isothermal bulk polymerization. They explained that one reason for this low polymerization of Bis-GMA is inhibition by atmospheric oxygen. Furthermore, with respect to inhibition of polymerization they found monomers containing long-chain members between 2 functional groups and those of high viscosity to be relatively few ${ }^{18)}$. We found that increasing amounts of TEDMA in monomer mixtures of Bis-GMA and TEDMA decreased the conversion of polymerization in air, since the rate of oxygen diffusion in a resin liquid increases with decreasing viscosity ${ }^{16)}$. Thus,

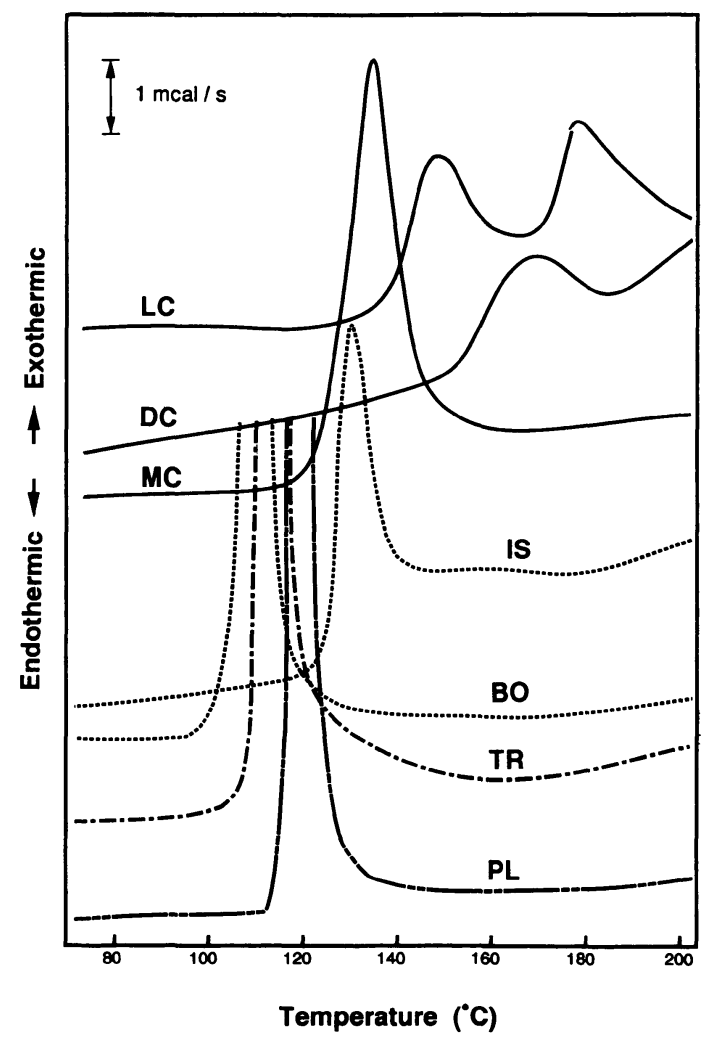

Fig. 2 Change in DSC curves during heating of crown and bridge veneering resins. Solid lines show visible light-cured resin pastes and other lines show heat-cured. 
although TEDMA is strongly inhibited by atmospheric oxygen, TEDMA showed a sharp exothermic peak. It thus seems that the heat curing behavior of dimethacrylate monomers depends on their chemical properties.

Many monomers appear to undergo spontaneous polymerization when heated in the apparent absence of catalysts. In most cases, the observed polymerizations are initiated by the thermal or photolytic homolysis of impurities (including peroxides or hydroperoxides formed due to $\mathrm{O}_{2}$ ) present in the monomer. Most monomers when exhaustively purified (and in exhaustively purified reaction vessels) do not undergo a purely thermal, self-initiated polymerization in the dark $^{30}$. Therefore, it seems that TEDMA showed spontaneous polymerization initiated by thermal homolysis of a peroxide due to $\mathrm{O}_{2}$.

Figure 4 shows the change in the DSC curves of 8 kinds of mixtures of Bis-GMA and catalysts. Sample A, Bis-GMA with $2 \mathrm{wt} \%$ BPO, showed a large exothermic peak, apparently due to the heat of polymerization. Sample C, Bis-GMA with 2 wt\% DMPT, showed a broad exothermic peak. Other mixtures showed no exothermic or endothermic peaks. It was found that a photoinitiation reagent like $C Q$ and combination of $C Q$ and various amines had little potential for heat curing. Therefore, although $\mathrm{OC}$ has a relatively high $\mathrm{CQ}$ content among these restorative composite resins (OC, $1.03 \mathrm{wt} \%$; PCA, $0.83 \mathrm{wt} \%$; LF, $0.35 \mathrm{wt} \%)^{7}$,

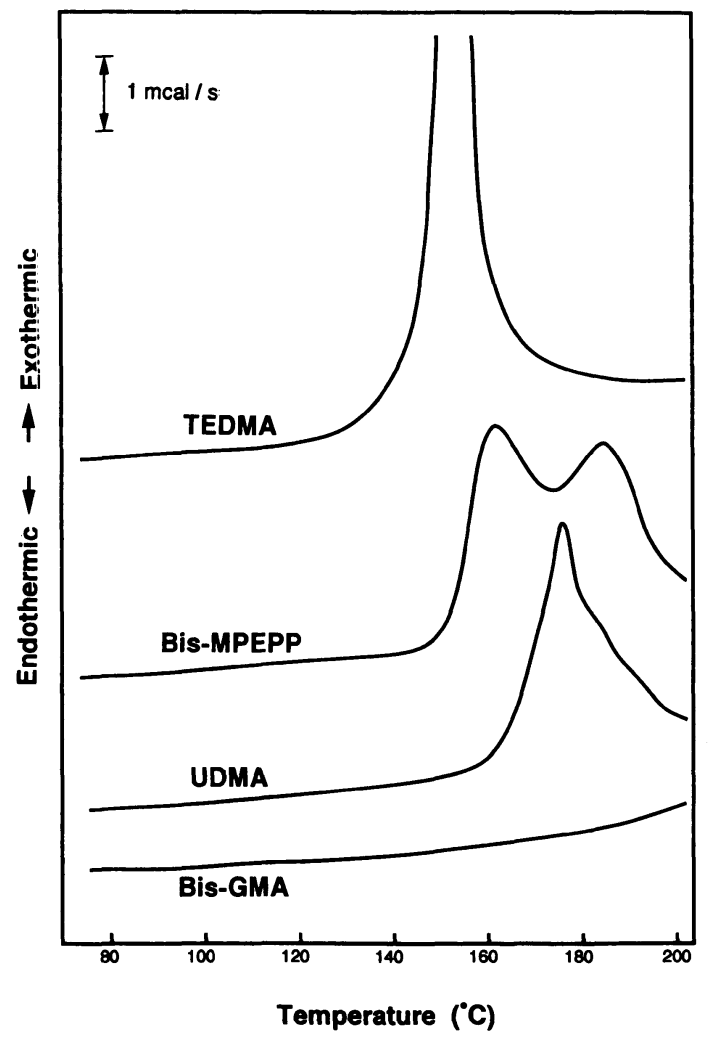

Fig. 3 Change in DSC curves during heating of 4 kinds of monomers without any additives. 
OC showed no change in the DSC curve from room temperature to $200^{\circ} \mathrm{C}$ as shown in Fig. 1. Taira et $a l^{6}{ }^{6}$ reported that $\mathrm{LF}$ and $\mathrm{OC}$ contain dimethyl-aminoethyl methacrylate (DMAEMA), but PCA contains an another undetected additive as a reducing agent. It is unclear whether the sharp exothermic peak in the DSC curve for PCA depends on the heat of polymerization initiated by the combination of $\mathrm{CQ}$ and an unknown reducing agent. Therefore, it is concluded that camphorquinone can not be accelerated by the application of heat.

Figure 5 shows changes in the DSC curves of 7 kinds of monomer mixtures without any catalysts. Pure TEDMA showed a sharp exothermic peak around $150^{\circ} \mathrm{C}$, as shown in Fig. 3. Monomer mixtures $\mathrm{I}, \mathrm{J}, \mathrm{K}$, and $\mathrm{L}$ containing TEDMA showed exothermic pesks corresponding to each major monomer except TEDMA. Monomer mixtures $\mathrm{M}, \mathrm{N}$, and $\mathrm{O}$ containing MMA, EMA, and EDMA showed no exothermic peaks in this temperature range. These monomers seem to evaporate during the measurement because of low boiling point (MMA, $100^{\circ} \mathrm{C}$; EMA, $30^{\circ} \mathrm{C}$; EDMA, $98^{\circ} \mathrm{C}$ ). Therefore, it seems that thermal behavior of monomer mixtures depends on that of the monomer and there is little change due to

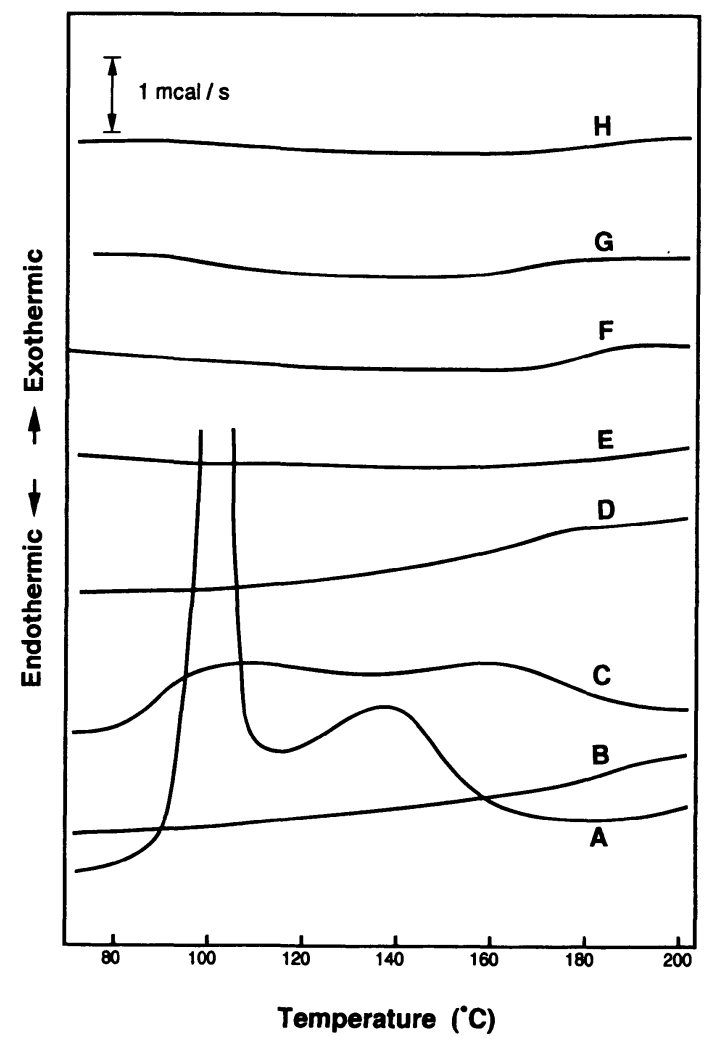

Fig. 4 Change in DSC curves during heating of 8 kinds of mixtures of Bis-GMA and catalysts: A, 2 wt $\%$ BPO;B, 2wt\% CQ;C, 2wt\% DMPT;D, 2 wt $\%$ DMAEMA; E, 2 wt $\%$ TEA ; F, 2 wt $\%$ CQ +2 wt $\%$ DMPT ; G, 2 wt $\%$ CQ+2 wt $\%$ DMAEMA; $\mathrm{H}, 2$ wt $\% \mathrm{CQ}+2$ wt $\%$ TEA. 
co-polymerization.

In the case of light-cured restorative composite resins, although PCA, LF and PF contain TEDMA, only PCA showed a sharp exothermic peak in the DSC curve. In the case of light-cured crown and bridge veneering resins, $\mathrm{MC}$ showed a sharp exothermic peak in the DSC curve. Although DC also contains TEDMA, it has no exothermic peak. Thus, it seems that the exothermic peaks of the DSC curve for light-cured commercial resins during heating depend on the heat of polymerization of each monomer itself contained in the resins, or the decomposition of heat-accelerated catalytic impurities in the manufacturers' products. Dynamic DSC measurement seems to be an adequate method for evaluation of the possibilities of heat curing of light-cured composite resins, and for discussion of the monomer composition and impurities of the monomers.

\section{CONCLUSION}

The heat curing behavior of light-cured restorative composite resins, light-cured crown

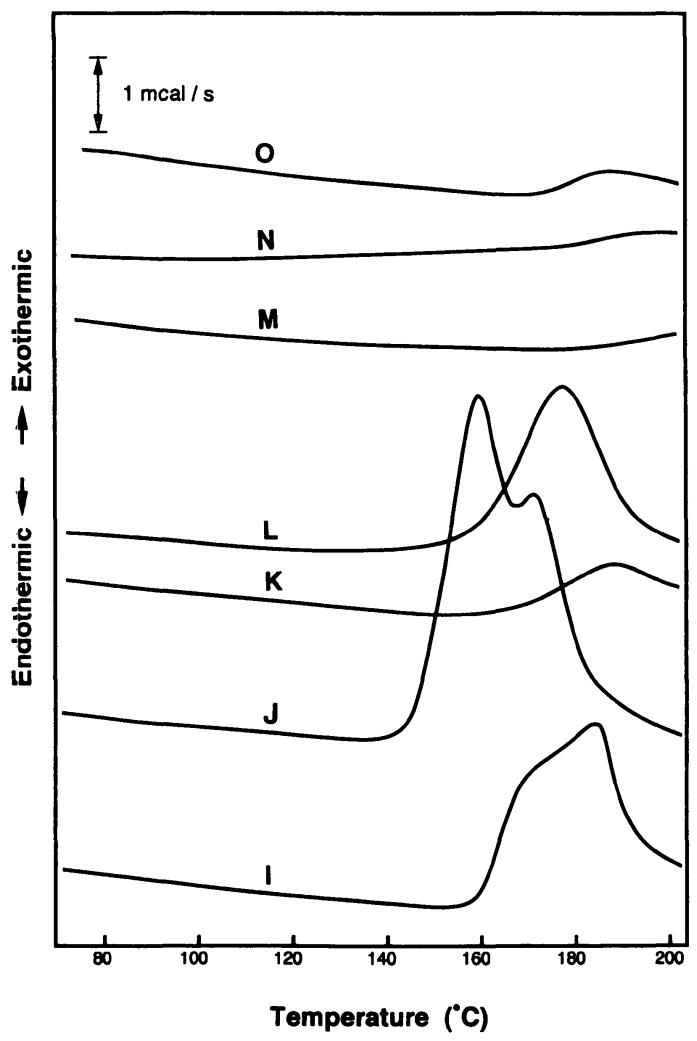

Fig. 5 Change in DSC curves during heating of 7 kinds of monomer mixtures without any catalyst : I, UDMA-10 wt\% TEDMA ; J, Bis-MPEPP-10 wt\% TEDMA ; K, Bis-GMA-10 wt\% TEDMA ; L, Bis-GMA-30 wt\% TEDMA ; M, Bis-GMA-10 wt\% MMA ; N, Bis-GMA-10 wt\% EMA ; O, Bis-GMA-10 wt\% EDMA. 
and bridge veneering resins, pure dimethacrylate monomers, Bis-GMA monomers containing various catalysts, and monomer mixtures were investigated by slow heating at a constant rate with differential scanning calorimetry (DSC) without any light irradiation - the so-called dynamic DSC measurement. Some of the light-cured restorative composite resins and the light-cured crown and bridge veneering resins showed a sharp exothermic peak around 110 $-130^{\circ} \mathrm{C}$ due to heat curing. Pure TEDMA also showed a sharp exothermic peak around $150^{\circ} \mathrm{C}$, whereas the Bis-GMA monomers containing catalysts for light curing showed no exothermic peak. It seems that heat curing behavior of light-cured composite resins depends not on the decomposition of camphorquinone, but on that of the monomer itself. It also seems that dynamic DSC measurement is an adequate method for evaluating heat curing of light-cured composite resins, and for discussion of the monomer composition and impurities in monomers.

\section{REFERENCES}

1) Cook, W. D. and Johannson, M. : The influence of postcuring on the fracture properties of photo-cured dimethacrylate based dental composite resin, J Biomed Mat Res 21: 979-989, 1987.

2) Terachi, M., Ujigo, Y., Muraki, T., Sato, K., Takemaru, A., Utsumi, S., Matsumura, K. and Inoue, K. : A study on composite resin inlay (part 4) The reinforcement of the mechanical properties of a light-cured composite resin, and the bonding property of a light-cured adhesive resin cement, Japan J Conserv Dent 32(1) : 95-101, 1989. (in Japanese)

3) Stanley, L. W.: Time as a factor in the heat curing of composite resins, Quint Intern 20(4) : 259-263, 1989.

4) Kanca III, John: The effect of heat on the surface hardness of light-activated composite resins, Quint Intern 20(12) : 899-901, 1989.

5) Brit. Patent, 1465897, 1977.

6) Taira, M., Urabe, H., Hirose, T., Wakasa, K. and Yamaki, M. : Analysis of photo-initiators in visiblelight-cured dental composite resins, $J$ Dent Res 67(1) : 24-28, 1988.

7) Shintani, H., Inoue, T. and Tamaki, M. : Analysis of camphorquinone in visible light-cured composite resins, Dent Mater 1: 124-126, 1985.

8) Ruyter, I. E. and Sjvik Kleven, I. J. : Monomers and filler content of resin-based crown and bridge materials, Dent Mater 3: 315-321, 1987.

9) Asmussen, E. : Restorative resins: hardness and strength vs. quantity of remaining double bonds, Scand J Dent Res 90 : 484-489, 1982.

10) Vankerckhoven, H., Lambrechts, P., Van Beylen, M., Davidson, C. L. and Vanherle, G.: Unreacted methacrylate groups on the surface of composite resins, J Dent Res 61(6) : 791-795, 1982.

11) Ban, S,. Mizumoto, A., Takahashi, Y., Mori, S., Iino, S. and Hasegawa, J.: Studies on setting reaction of composite resins-Factors affecting the copolymerization rection of Bis-GMA with TEDMA-, Aichi-Gakuin J Dent Sci 21(2) : 433-439, 1983. (in Japanese)

12) McCabe, J. F. and Wilson, H. J. : The use of differential scanning calorimetry for evaluation of dental materials, J Oral Rehab 7 : 103-110, 1980.

13) McCave, J. F.: Cure performance of light-activated composites by differential thermal analysis (DTA), Dent Mater 1: 231-234, 1985.

14) Antonucci, J. M. and Toth, E. E. : Extent of polymerization of dental resins by differential scanning calorimetry, J Dent Res 62(2) : 121-125, 1985.

15) Ban, S., Mizumoto, A., Takahashi, Y., Hayashi, K., Kato, H. and Hasegawa, J. : Studies on setting reaction of composite resins. Heat of polymerization investigated by isothermal DSC measurement (part 1), Aichi-Gakuin J Dent Sci 21(4) : 685-693, 1983. (in Japanese)

16) Ban, S. and Hasegawa, J.: Heat of polymerization of dimethacrylate monomers investigated by isothermal DSC measurement, Dent Mater J 3(1) : 85-92, 1984. 
17) Miyazaki, K., Kawaguchi, M., Horibe, T. and Mizukami, Y.: The polymerization reaction of dimethacrylates (1) Isothermal bulk polymerization I, J J Dent Mater 4(5) : 504-510, 1985. (in Japanese)

18) Miyazaki, K., Kawaguchi, M., Inoue, Y. and Horibe, T.: The polymerization reaction of dimethacrylates (2) Isothermal bulk polymerization II, J J Dent Mater 4(6) : 701-707, 1985. (in Japanese)

19) Komoto, T., Fujiwara, H., Miyazaki, K. and Horibe, T. : Polymerization reaction of heat curing type thermo-setting resin for crown and bridge, J Japan Prosthodont Dent 32: 92-98, 1988. (in Japanese)

20) Lee, H. and Colby, C.: Heat of polymerization of nine, mono-, di, and trimethacrylate esters tested neat and with low levels of peroxide by dynamic differential scanning calorimetry, Dent Mater $2: 175$ $-178,1986$.

21) Kojima, K., Kubota, T., Kadoma, Y. and Masuhara, E. : Studies on hardening behavior of visible-light cured composite resins, $J$ J Dent Mater 1(4): 373-382, 1982. (in Japanese)

22) Kadoma, Y., Kojima, K. and Masuhara, E. : Studies on initiator systems of visible-light curing resins using DSC, $J$ J Dent Mater 5(3) : 341-348, 1986. (in Japanese)

23) Abadie, M. J. M., Appelt, B. K. : Photocalorimetry of light-cured dental composites, Dent Mater 5: 6 $-9,1989$.

24) Ban, S., Tsuruta, S., Ishigure, K., Mizutani, M., Mieki, A., Kitaoka, M., Okushima, R. and Hasegawa, J. : Properties of light-cured crown and bridge veneering resins, Aichi-Gakuin J Dent Sci 26(2) : 353360, 1988. (in Japanese)

25) Ogura, M.: Study on the light cured composite resins - Consideration of thickness of low polymerized zone on the surface of composites by knoop hardness measurements - Japan J Conserv Dent 30(4) : 1172-1184, 1987. (in Japanese)

26) Inoue, K., Miura, K., Funada, M., Ishizawa, S., Tabata, Y., Ginya, K., Nihara, A., Uchiyama, C. and Kuroki, K. : Physical and mechanical properties of light activated composite resins, Dental Outlook 68(4) : 799-808, 1986. (in Japanese)

27) Nomoto, R., Endo, K., Hirabayashi, S. and Hirasawa, T.: Effects of irradiation time on the conversion of light-cured composite resins for the molar region, $J$ J Dent Mater 5 special 7: 105-106, 1986. (in Japanese)

28) Ishikawa, A. : Curing shrinkage and analysis on the composition of composite resins, Japan J Conserv Dent 29(1) : 129-170, 1986. (in Japanese)

29) Hirasawa, T., Harashima, I., Nomoto, R., Uasa, S., Uzawa, T. and Okubo, K. : Comparison of composition and properties of crown and bridge veneering resins, $D E 85: 16-17,1988$. (in Japanese)

30) Odian, G.: Principles of polymerization, John Wiley \& Sons, New York, 1981, pp. 194-223. 
Dentin primer 塗布によるウサギの皮膚に対する病理学的変化の研究

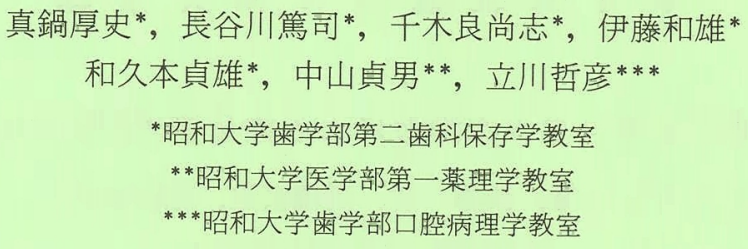

レジンの象牙質に対する接着性を改善するために用い られる dentin primerによって，術者の手指を主とする 皮膚組織に引き起こされる副作用を検討するために, glutaraldehyde (GLU) または HEMA の水溶液，およ びこれらの混合水溶液からなる試作 primerの7日間の 反復塗布によって, ウサギの皮膚に見られる変化を病理 学的に検討した。さらに, 新たに試作した dimethylaminoethyl methacrylate (DMAEM) 水溶液の接着 性を検討するとともに，この水溶液による副作用も合わ
せて検討した。その結果, DMAEM は従来報告されてい る, HEMA および GLU を含む水溶液と同等の接着性を 示したものの, ウサギの皮膚に対して強力な炎症作用を 引き起こし,さらに,このような炎症は, 滁布 7 日後に も完全に回復することは出来なかった。さらに, GLUを 含む水溶液でも同様の炎症が惹起されたが，その程度は やや軽微で，7日後にはほぼ完全な回復が観察された。 これに対して HEMA および glyceryl methacrylateの 塗布では，著明な変化は全く認められなかった。

DSC 昇温法による光重合型コンポジットレジンの熱重合の研究

伴 清治, 高橋好文, 棚瀬裕明, 長谷川二郎

愛知学院大学歯学部歯科理工学教室

成形修復用光重合型コンポジットレジン，歯冠修復用 光重合型硬質レジン, 純粋ジメタクリレートモノマー, 触媒を添加した Bis-GMA，モノマー混合物の熱重合挙 動を, 走查型示差熱量測定 (DSC) により, 光照射せず に, 一定の昇温速度でゆっくり過熱した場合，すなわち DSC 昇温法により測定した。成形修復用光重合型コンポ ジットレジンおよび歯冠修復用光重合型硬質レジンの中
には，大きな発熱ピークを示すものがあった。また，純 粋 TEDMA モノマーも大きな発熱ピークを示した。一 方, カンファーキノンを添加した Bis-GMA は発熱ピー クは生じなかった。ゆえに, 光重合型コンポジットレジ ンの熱重合挙動はカンファーキノンの熱分解によるもの ではなく、レジン成分であるモノマー自体の熱重合によ るものと考えられた。

HEMA 水溶液の象牙質知覚鎮静効果に関する臨床的評価 須田玲子*, 安藤芳明*, 塩野目学 ${ }^{*}$, 長谷川紘司 ${ }^{*}$

伊藤和雄 ${ }^{* *}$, 和久本貞雄 $* *$

*昭和大学歯学部第歯科保存学第 3 講座

**昭和大学歯学部第歯科保存学第 2 講座

象牙質知覚過敏症に対する $35 \% \mathrm{HEMA}$ 水溶液の鎮 静効果を臨床的に評価するために, 歯周治療を要する 48 患歯の歯面をEDTAによって清掃し，35\% HEMA 水
溶液を塗布して市販の dentin bonding agentで被覆し た。このような手法による知覚鎮静効果は, 圧搾空気, 冷水，および探針によって歯面を刺激した際の反応を， 